\title{
A Tentative Model to Describe the Respiration of Stored Apples
}

\author{
G. Andrich, R. Fiorentini, A. Tuci, A. Zinnai, and G. Sommovigo \\ Istituto di Industrie Agrarie, University' di Piss, Via S. Michele degli Scalzi 4, 56124 Piss, Italy
}

Additional index words. Malus dornestica, respiration, mathematical models, kinetics

\begin{abstract}
Using mathematical equations that describe the $0_{2}$ mass-transfer and the enzymatic oxidation of the organic substrates of apples (Malus domestica Borkh.), we developed a kinetic model to correlate fruit respiration rate with environmental oxygen partial pressure $\left(\mathrm{PO}_{2}\right.$. The kinetic determinations were carried out at room temperature using apples stored at 3 to $4 \mathrm{C}$ for 11 to 19 weeks. Results show that: 1) the calculated value of the Michaelis-Menten constant related to the enzymatic oxidation of the respiratory substrate $\left(K_{m}=2.1 \pm 0.5 .10^{-5} \mathrm{~mol}^{\circ} \mathrm{kg}^{-1}\right)$ is close to that reported in the literature for cytochrome-c oxidase; 2) the located range of $\mathrm{PO}_{2}$ levels where $\mathrm{O}_{2}$ becomes the limiting factor in the respiration process (near $2.6 \mathrm{kPa}$ at $\mathrm{T}=20.5 \pm \mathrm{IC}$ ) is close to those usually used on a commercial scale for controlled atmosphere storage.
\end{abstract}

\begin{abstract}
Although much technical information has been published on the storage of fresh fruits (Biale and Young, 1981; Burton, 1978; Isenberg, 1979; Smock, 1979; Tucker and Laties, 1985), a kinetic model describing the main biochemical changes occurring in the stored fruit as a result of its respiration activity is not available.
\end{abstract}

From a kinetic point of view, respiration can be simplified into three steps: 1) $\mathrm{O}_{2}$ mass-transfer between the environmental atmosphere and the cellular solution of the fruits; 2) $\mathrm{O}_{2}$ use and $\mathrm{CO}_{2}$ production inside the cells; and 3 ) the consequent masstransfer of $\mathrm{CO}_{2}$ from the cellular solution to reach the environmental atmosphere.

The $\mathrm{O}_{2}$ and $\mathrm{CO}_{2}$ mass-transfers between the apple and its storage environment have been investigated; the results obtained and the experimental method and hypothesized equations used have been reported (Andrich et al., 1987, 1988, 1989a, 1989b, 1990; Fiorentini et al., 1986). To describe the mass transfer rate of the two gases involved in respiration, the following equation related to the mass-transfer between two heterogeneous phases (gas-and apple) was adopted (Danckwerts, 1970; Sinclair, 1987):

$\mathrm{V}_{\mathrm{mt}}=\mathrm{k}_{-\mathrm{i}} \cdot \mathrm{A} \cdot\left(\left[\mathrm{O}_{2}\right]_{\mathrm{eq}}-\left[\mathrm{O}_{2}\right]\right)=\mathrm{k}_{-\mathrm{i}} \cdot \mathrm{A} \cdot\left(\mathrm{H} \cdot \mathrm{PO}_{2}-\left[\mathrm{O}_{2}\right]\right)$

where: $\left[\mathrm{O}_{2}\right]=$ concentration of oxygen present inside $1 \mathrm{~kg}$ of apples at a random time $\mathrm{t}=\mathrm{t}\left(\mathrm{mol} \cdot \mathrm{kg}^{-1}\right) ; \mathrm{k}_{-\mathrm{i}}=$ kinetic constant related to the apple-phase $\left(\mathrm{kg} \cdot \mathrm{m}^{-2} \mathrm{~h}^{-1}\right) ; \mathrm{A}=$ surface area related to $1 \mathrm{~kg}$ of the considered apples $\left(\mathrm{m}^{2} \cdot \mathrm{kg}^{-1}\right) ;\left[\mathrm{O}_{2}\right]_{\text {eq }}=$ concentration of $\mathrm{O}_{2}$ inside the apples that would be in equilibrium with the partial pressure $\left(\mathrm{PO}_{2}\right)$ of $\mathrm{O}_{2}$ present at a random time $\mathrm{t}=$ tin the environmental atmosphere $\left(\mathrm{mol} \cdot \mathrm{kg}^{-1}\right) ; \mathrm{H}=$ Henry's constant related to the saturation equilibrium $=\left[\mathrm{O}_{2}\right]_{\mathrm{eq}} /$ $\mathrm{PO}_{2}\left(\mathrm{~mol} \cdot \mathrm{kg}^{-1} \cdot \mathrm{Pa}^{-1}\right)$. If the analyzed system has reached the steady state so that the respiration rate equals the rate of mass transfer, Eq. [1] allows us to calculate the amount of $\mathrm{O}_{2}$ present inside the apple $\left(\left[\mathrm{O}_{2}\right]\right)$. This quantity is closely related to the second step of the hypothesized kinetic model, which concerns the cellular oxidation of the respiration substrates.

If the respiration rate is directly related to the amount of $\mathrm{O}_{2}$ dissolved in the cellular solution, the Michaelis-Menten equation can be applied and the suitability of the values of the in-

\footnotetext{
Received for publication 7 Mar. 1990. Research supported by National Research Council of Italy, Special Project RAISA, Subproject no. 4, Paper no. 9. The cost of publishing this paper was defrayed in part by the payment of page charges. Under postal regulations, this paper therefore must be hereby marked advertisement solely to indicate this fact.
}

volved constants $\left(\mathrm{Km}=\right.$ Michaelis's constant and $\mathrm{k}_{\mathrm{res}}=$ kinetic constant) can also be verified.

\section{Materials and Methods}

The experimental runs were carried out using 'Golden Delicious' apples, carefully followed during their ripening and harvested at color change ( 22 weeks from flowering). Only healthy looking apples were collected and stored at 3 to $4 \mathrm{C}, 85 \% \mathrm{RH}$, for 11 to 19 weeks. Beginning the 1lth week of storage, a sample of 13 to 15 healthy apples was taken each week and used for an experimental run carried out at room temperature $(20.5 \pm 1$. OC) .

The handling of the fruits and the method used to determine the surface area of the apples have been reported (Andrich et al., 1989a; Fiorentini et al., 1986). The system used to follow the $\mathrm{O}_{2}$ respired and the $\mathrm{CO}_{2}$ produced is illustrated in Fig. 1. $\mathrm{PO}_{2}$ in the system was verified by gas chromatography.

The $\mathrm{CO}_{2}$ produced was collected as $\mathrm{BaCO}_{3}$ by continuously washing the gas in the apparatus with an aqueous solution of $\mathrm{Ba}(\mathrm{OH})_{2}$. The $\mathrm{BaCO}_{3}$ precipitated was removed by filtration and the residual concentration of $\mathrm{OH}^{-}$was evaluated by titration. To maintain a constant gas composition inside the reactor $\left(\mathrm{PO}_{2}=\right.$ initial value and $\left.\mathrm{PCO}_{2} \simeq 0\right)$, the volume of absorbed $\mathrm{CO}_{2}$ was continuously and automatically replenished by pure $\mathrm{O}_{2}$, thus allowing the respiration rate of the apples to be calculated. The difference between the $\mathrm{CO}_{2}$ produced and the $\mathrm{O}_{2}$ consumed gave a measure of the eventual fermentation activity, a process not detectable at high $\mathrm{O}_{2}$ concentrations $\left(\mathrm{PO}_{2}>5\right.$ $\mathrm{kPa})$.

The amounts of glucose, fructose, sucrose, glucitol, and malic acid in the fruit were determined using commercial enzyme kits.

Abbreviations: A, surface area of fruit per unit weight $\left(\mathrm{m}^{2} \cdot \mathrm{kg}^{-1}\right)$; d, density of fruit $\left(\mathrm{kg} \cdot \mathrm{1}^{-1}\right) ; \mathrm{H}$, equilibrium constant $\mathrm{H}$ involved in mass-transfer of $\mathrm{O}_{2}$ $\left(\mathrm{mol} \cdot \mathrm{kg}^{-1} \cdot \mathrm{Pa}^{-1}\right) ; \mathrm{k}_{-\mathrm{i}}$, kinetic constant involved in mass-transfer of $\mathrm{O}_{2}$ $\left(\mathrm{kg} \cdot \mathrm{m}^{-2} \cdot \mathrm{h}^{-1}\right) ; \mathrm{k}_{\text {res}}$, product of kinetic constant and enzymatic concentration $\left(\mathrm{mol} \cdot \mathrm{kg}^{-1} \cdot \mathrm{h}^{-1}\right) ; \mathrm{K}_{1}$, equilibrium constant between $\left[\mathrm{O}_{2}\right]_{\text {c.s. }}$ and $\mathrm{PO}_{2(\mathrm{i} . \mathrm{s} .)}$ $\left(\mathrm{mol} \cdot \mathrm{kg}^{-1} \cdot \mathrm{Pa}^{-1}\right) ; \mathrm{K}_{2}$, equilibrium constant between $\left[\mathrm{O}_{2}\right]$ c.s. $/\left[\mathrm{O}_{2}\right]$ i.s.; $\mathrm{K}_{\mathrm{m}}$, Michaelis-Menten constant $\left(\mathrm{mol} \cdot \mathrm{kg}^{-1}\right) ;\left[\mathrm{O}_{2}\right]$, concentration of oxygen inside apple at a random time $\mathrm{t}=\mathrm{t}\left(\mathrm{mol} \cdot \mathrm{kg}^{-1}\right) ;\left[\mathrm{O}_{2}\right]_{\mathrm{c.s} \text {, }}$, concentration of $\mathrm{O}_{2}$ dissolved in the cellular soap $\left(\mathrm{mol} \cdot \mathrm{kg}^{-1}\right) ;\left[\mathrm{O}_{2}\right]_{\text {eq }}$, concentration of $\mathrm{O}_{2}\left(\mathrm{~mol} \cdot \mathrm{kg}^{-1}\right)$ in apple and in equilibrium with partial pressure of $\mathrm{O}_{2}$ in the atmosphere; $\left[\mathrm{O}_{2}\right]_{\mathrm{i} . \mathrm{s} \text {, }}$, concentration of $\mathrm{O}_{2}$ present in intercellular space $\left(\mathrm{mol} \cdot \mathrm{kg}^{-1}\right) ; \mathrm{PO}_{2}$, partial pressure of $\mathrm{O}_{2}$ in the atmosphere $(\mathrm{Pa}) ; \mathrm{PO}_{2(\mathrm{i} . s .)}$, partial pressure of $\mathrm{O}_{2}$ in intercellular space $(\mathrm{Pa}) ; \mathrm{R}$, ideal gas constant $\left(\mathrm{Pa} \cdot 1 \cdot \mathrm{mol}^{-1} \cdot \mathrm{K}^{-1}\right) ; \mathrm{T}$, temperature $(\mathrm{K}) ; \mathrm{V}_{\mathrm{i} . \mathrm{s}}$, volume of intercellular space (1); $\mathrm{V}_{\mathrm{m},}, \mathrm{O}_{2}$ mass-transfer rate $\left(\mathrm{mol} \cdot \mathrm{kg}^{-1} \cdot \mathrm{h}^{-1}\right)$; $\mathrm{V}_{\text {res }}$, respiration rate $\left(\mathrm{mol} \cdot \mathrm{kg}^{-1} \cdot \mathrm{h}^{-1}\right) ; \mathrm{w}$, weight of fruit $(\mathrm{kg})$. 


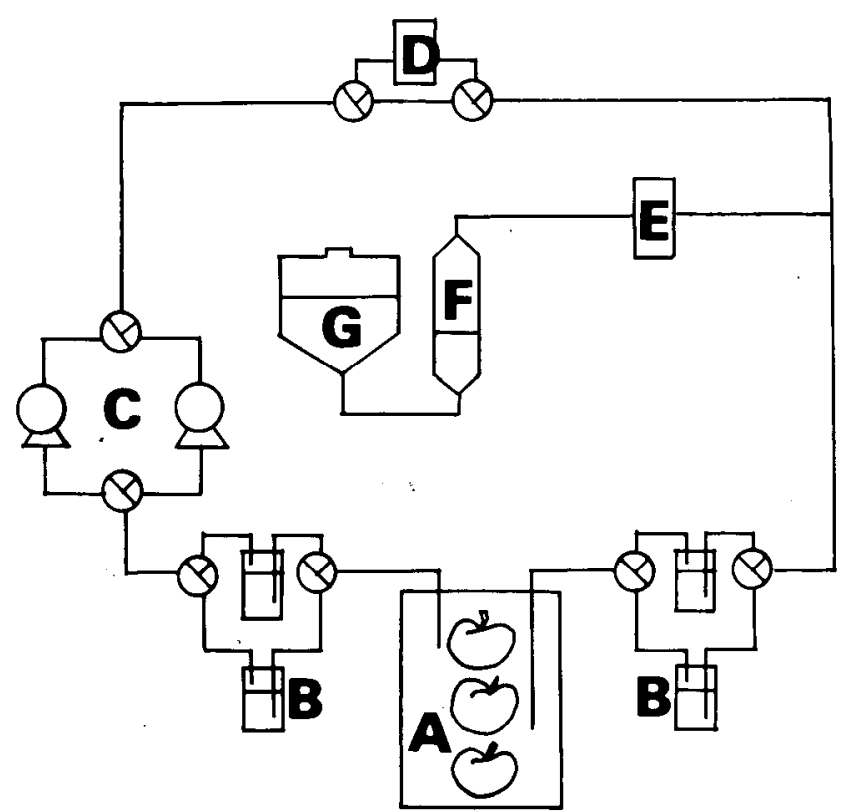

Fig. 1. Simplified scheme of the system used: $\mathrm{A}=$ reactor filled with apples; $\mathrm{B}=$ traps to collect $\mathrm{CO}_{2}$ produced; $\mathrm{C}=$ circulating pumps; $\mathrm{D}=$ gas chromatography; $\mathrm{E}=$ one-way valve; $\mathrm{F}=$ graduated $\mathrm{O}_{2} \operatorname{tank} ; \mathrm{G}=\operatorname{tank}$ filled with saturated aqueous solution $(\mathrm{NaCl})$.

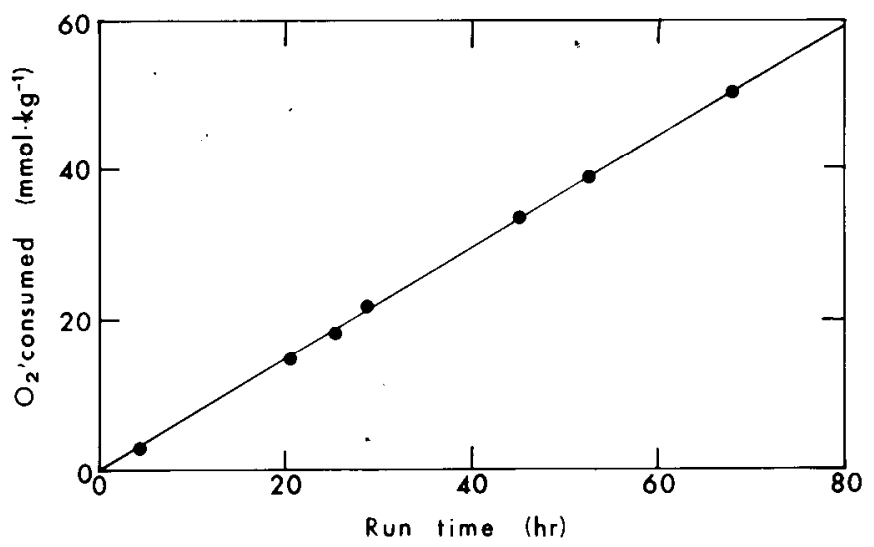

Fig. 2. Oxygen consumed by apples at a constant $\mathrm{PO}_{2}$ and at $\mathrm{PCO}_{2}$ $\simeq 0\left(\mathrm{~T}=20.5 \mathrm{C} ; \mathrm{PO}_{2}=16.3 \mathrm{kPa} ; \mathrm{PN}_{2}=83.7 \mathrm{kPa} ; \mathrm{RH}=85 \%\right)$. The experimental points reflect a random run.

\section{Results}

By the linear regression of the experimental data for $\mathrm{O}_{2}$ consumption, measured at constant $\mathrm{PO}_{2}$ and at $\mathrm{PCO}_{2} \approx 0$, as a function of the related run time, it was possible to draw a straight line through the origin of the axes and to obtain a high correlation coefficient (Fig. 2). The slope of this line represents the respiration rate $\left(\mathrm{V}_{\text {res }}\right)$ of the apples under our experimental conditions. The values for $\mathrm{V}_{\text {res }}$, determined as a function of the various $\mathrm{PO}_{2}$ and of the storage time used for the apples are reported in Table 1 . The confidence intervals $(95 \%)$ are a function of the variance connected with the related linear regression (see note to Table 1).

At similar $\mathrm{PO}_{2}$ levels, results were similar for samples stored for various periods. Under these experimental conditions, therefore, storage time did not seem to significantly influence the respiration rate, as already reported by Knee (1971).

When an apple-environment system reaches the steady state,
Table 1. Respiration rates $\left(\mathrm{V}_{\text {res }}\right)$ at $21 \pm 1 \mathrm{C}$ and the related $95 \%$ confidence intervals (c.i.) as a function of the $\mathrm{PO}_{2}$ used and the corresponding storage times ( 3 to $4 \mathrm{C} ; 85 \% \mathrm{RH})$.

\begin{tabular}{|c|c|c|c|}
\hline $\begin{array}{c}\text { Storage time } \\
\text { (weeks from } \\
\text { harvest) }\end{array}$ & $\begin{array}{r}\mathrm{PO}_{2} \\
(\mathrm{kPa}) \\
\end{array}$ & $\begin{array}{c}\mathrm{V}_{\text {res }} \\
\left(\mathrm{mmol} \cdot \mathrm{kg}^{-1} \cdot \mathrm{h}^{-1}\right) \\
\end{array}$ & c.i. ${ }^{y}$ \\
\hline 19 & 1.9 & 0.28 & 0.04 \\
\hline 19 & 2.8 & 0.36 & 0.03 \\
\hline 18 & 3.2 & 0.41 & 0.02 \\
\hline 19 & 3.4 & 0.43 & 0.05 \\
\hline 17 & 3.7 & 0.51 & 0.06 \\
\hline 12 & 3.8 & 0.53 & 0.06 \\
\hline 17 & 3.8 & 0.45 & 0.03 \\
\hline 12 & 3.8 & 0.45 & 0.05 \\
\hline 14 & 4.3 & 0.48 & 0.03 \\
\hline 11 & 4.7 & 0.47 & 0.03 \\
\hline 18 & 4.8 & 0.48 & 0.06 \\
\hline 15 & 5.1 & 0.59 & 0.02 \\
\hline 14 & 6.5 & 0.55 & 0.04 \\
\hline 11 & 6.6 & 0.58 & 0.06 \\
\hline 17 & 6.6 & 0.55 & 0.05 \\
\hline 12 & 7.7 & 0.53 & 0.03 \\
\hline 17 & 7.7 & 0.52 & 0.02 \\
\hline 16 & 14.2 & 0.72 & 0.03 \\
\hline 11 & 15.9 & 0.74 & 0.05 \\
\hline 16 & 16.2 & 0.64 & 0.06 \\
\hline 19 & 16.3 & 0.75 & 0.06 \\
\hline 13 & 16.4 & 0.69 & 0.02 \\
\hline 18 & 16.7 & 0.79 & 0.07 \\
\hline 15 & 25.1 & 0.79 & 0.02 \\
\hline 11 & 26.3 & 0.63 & 0.02 \\
\hline 15 & 26.7 & 0.84 & 0.05 \\
\hline 16 & 27.3 & 0.83 & 0.01 \\
\hline 16 & 27.5 & 0.74 & 0.04 \\
\hline 13 & 28.4 & 0.59 & 0.04 \\
\hline 15 & 28.4 & 0.59 & 0.06 \\
\hline
\end{tabular}

Thirty-ninth week of year.

${ }^{y}$ c. i. = confidence interval of related $V_{\text {res }}=t_{0.05} \cdot d_{v_{\text {res }}}$ where: $t_{0.05}=$ value tabulated as a function of degree of freedom (df); $\mathrm{df}=\mathrm{N}-2$; $\mathrm{N}=$ no. experimental points involved in considered linear regression; $\mathrm{d}_{\mathrm{Vres}}=\left(\left(\mathrm{N} /\left(\mathrm{N} \cdot \sum_{\mathrm{i}=1}^{\mathrm{N}} \mathrm{X}_{\mathrm{i}}^{2}-\left(\sum_{\mathrm{i}=1}^{\mathrm{N}} \mathrm{X}_{\mathrm{i}}\right)^{2}\right)\right) \cdot\left(\sum_{\mathrm{i}=1}^{\mathrm{N}}\left(\mathrm{Z}_{\mathrm{i}}-\mathrm{V}_{\mathrm{res}} \cdot \mathrm{X}_{\mathrm{i}}\right)^{2}\right) /(\mathrm{N}-2)\right)^{0.5}$; $\mathrm{X}_{\mathrm{i}}=$ run time related to an experimental determination; $\mathrm{Z}_{\mathrm{i}}=$ experimental amount of oxygen respired at considered run time.

$\mathrm{V}_{\mathrm{res}}=\mathrm{V}_{\mathrm{mt}}$ and, knowing the values for the respiration rate (Table 1) and for the parameters $\mathrm{k}_{\mathrm{i}}$ and $\mathrm{H}$ involved in the masstransfer Eq. [1], it is possible to calculate the amount of $\mathrm{O}_{2}$ present inside the apples by:

$$
\left[\mathrm{O}_{2}\right]=\mathrm{H} \cdot \mathrm{PO}_{2}-\mathrm{V}_{\mathrm{res}}\left(\mathrm{k}_{-\mathrm{i}} \cdot \mathrm{A}\right)
$$

where: $\mathrm{A}=0.110 \pm 0.003\left[\mathrm{~m}^{2} \cdot \mathrm{kg}^{-1}\right] ; \mathrm{k}_{-\mathrm{i}}=18.7 \pm 1.9$ $\left[\mathrm{kg} \cdot \mathrm{h}^{-1} \cdot \mathrm{m}^{-2}\right]$ (Andrich et al., 1989b); $\mathrm{H}=0.14 \pm 0.02$ $\left[\mathrm{mmol} \cdot \mathrm{kg}^{-1} \cdot \mathrm{kP}^{-1}\right]$ (Andrich et al., 1989b).

To correlate $\mathrm{V}_{\text {res }}$ with the $\mathrm{O}_{2}$ concentration in the cellular solution $\left(\left[\mathrm{O}_{2}\right]_{\text {c.s. }}\right)$, the existence of an instantaneous equilibrium between the intercellular $\mathrm{O}_{2}\left(\left[\mathrm{O}_{2}\right]_{\text {i.s. }}\right)$ and $\left[\mathrm{O}_{2}\right]_{\text {c.s. }}$ has been assumed, in accordance with the hypothesis of our kinetic model (Andrich et al., 1989a). The value of the equilibrium constant $\mathrm{K}_{1}$ between $\left[\mathrm{O}_{2}\right]_{\text {c.s. }}$ and the corresponding partial pressure of $\mathrm{O}_{2}$ in the intercellular space $\left(\mathrm{PO}_{2(\text { i.s. })} \mathrm{T}\right)$ can then be calculated if, in accordance with Burton (1974), the cellular solution is assumed to be a $0.4 \mathrm{M}$ sucrose solution:

$$
\mathrm{K}_{1}=\left[\mathrm{O}_{2}\right]_{\text {c.s. }} / \mathrm{PO}_{2(\mathrm{i} . \mathrm{s.} .)}=1.35 \cdot 10^{-8}\left(\mathrm{~mol} \cdot \mathrm{kg} \quad{ }^{-1} \cdot \mathrm{Pa}^{-1}\right)
$$


Therefore, the $\mathrm{K}_{1}$ value has been calculated using data on the equilibrium between the $\mathrm{O}_{2}$ present in the gas phase and that dissolved in a $0.4 \mathrm{M}$ sucrose solution (Burton, 1974).

If one knows the total amount of $\mathrm{O}_{2}$ present inside $1 \mathrm{~kg}$ of apples and the value of the constant $\mathrm{K}_{1}$ at various environmental $\mathrm{PO}_{2}$, one can calculate the corresponding amount of $\mathrm{O}_{2}$ dissolved in the cellular solution. In fact, assuming the intercellular space $\left(\mathrm{V}_{\mathrm{is.}}\right)$ to be $21 \%$ of the total fruit volume (Baumann and Henze, 1983), it is possible to express $\left[\mathrm{IO}_{2}\right]_{\mathrm{is.}}$ as a function of $\mathrm{P} \mathrm{O}_{2(\mathrm{is.})}$ :

$$
\begin{aligned}
& {\left[\mathrm{O}_{2}\right]_{\text {i.s. }}=\cdot \mathrm{PO}_{2(\mathrm{i} . \mathrm{s.})} \cdot \mathrm{V}_{\mathrm{i} \text { i.s. }} /(\mathrm{w} \cdot \mathrm{R} \cdot \mathrm{T})=} \\
& \mathrm{PO}_{2(\text { i.s. })} \cdot 0.21 /(\mathrm{d} \cdot \mathrm{R} \cdot \mathrm{T})=1.02 \cdot 10^{-7} \cdot \mathrm{PO}_{2 \text { (i.s. })}
\end{aligned}
$$

where: $\mathrm{w}=$ weight of apples $(\mathrm{kg}) ; \mathrm{R}=$ ideal gas constant $\left(\mathrm{Pa} \cdot\right.$ liter $\left.\cdot \mathrm{mol}^{-1} \cdot \mathrm{K}^{-1}\right)$; $\mathrm{T}=$ temperature $(295 \mathrm{~K})$; and $\mathrm{d}=$ density of apples $\left(0.85 \mathrm{~kg} \cdot \mathrm{liter}^{-1}\right)$.

Combining Eqs. [3] and [4], it is possible to correlate $\left[\mathrm{O}_{2}\right]_{c \text { cs }}$ with $\left[\mathrm{O}_{2}\right]_{\text {is. }}$ to obtain the nondimensional constant $\mathrm{K}_{2}: \mathrm{K}_{2}=$ $\left[\mathrm{O}_{2}\right]_{\text {c.s. }} /\left[\mathrm{O}_{2}\right]_{\text {iss }}=1.35 \cdot 10^{-8} / 1.02 \cdot 10^{-7}=0.132 ;$ and as: $\left[\mathrm{O}_{2}\right]$ $=\left[\mathrm{O}_{2}\right]_{\text {is. }}+\left[\mathrm{O}_{2}\right]_{\text {c.s. }}$, the following equation, giving the amount of $\mathrm{O}_{2}$ dissolved in the cellular solution as a function of the $\mathrm{O}_{2}$ that has permeated into the fruit, is obtained:

$$
[\mathrm{O}]_{\text {c.s. }}=0.117 \cdot\left[\mathrm{O}_{2}\right]
$$

Moreover, the related value of $\mathrm{V}_{\text {res }}$ being known, it then becomes possible to evaluate directly the amount of $\left[\mathrm{O}_{2}\right]_{\text {c.s }}$ as a function of the environmental $\mathrm{PO}_{2}$ :

$$
\left[\mathrm{O}_{2}\right]_{\text {c.s. }}=0.117 \cdot\left(\mathrm{H} \cdot \mathrm{PO}_{2}-\mathrm{V}_{\mathrm{res}} /\left(\mathrm{k}_{\mathrm{-i}} \cdot \mathrm{A}\right)\right)
$$

As, under our experimental conditions, the concentrations of the main apple constituents (glucose, fructose, sucrose, glucitol, and malic acid) did not seem to vary with storage time (Table 2) sufficiently to change the total amount of respiratory substrate (assumed to be the molar sum of all the respirable compounds present inside $1 \mathrm{~kg}$ of fruit) nor to affect the respiration rate, the-following equation could be adopted (Michaelis-Menten):

$$
\mathrm{V}_{\text {res }}=\mathrm{k}_{\mathrm{res}} \cdot\left[\mathrm{O}_{2}\right]_{\text {c.s. }} /\left(\mathrm{K}_{\mathrm{m}}+\left[\mathrm{O}_{2}\right]_{\text {c.s. }}\right)
$$

where: $k_{\text {res }}=$ product of the kinetic constant and the enzymatic concentration corresponding to the maximum respiration rate $\left(\mathrm{mol} \cdot \mathrm{kg}^{-1} \cdot \mathrm{h}^{-1}\right) ; \mathrm{K}_{\mathrm{m}}=$ Michaelis-Menten constant $\left(\mathrm{mol} \cdot \mathrm{kg}^{-1}\right)$.

To determine $\mathrm{k}_{\mathrm{res}}$ and $\mathrm{K}_{\mathrm{m}}$, the inverse of the respiration rates reported in Table $1\left(1 / \mathrm{V}_{\text {res }}\right)$ were plotted as a function of the inverse of the related amounts of $\mathrm{O}_{2}$ dissolved in the cellular solution $\left(1 /\left[\mathrm{O}_{2}\right]_{\text {c.s. }}\right)$, which were calculated by Eq. [2] (Fig. 3): $1 / \mathrm{V}_{\text {res }}=\mathrm{K}_{\mathrm{m}} / \mathrm{k}_{\text {res }} \cdot 1 /\left[\mathrm{O}_{2}\right]_{\mathrm{c} . \mathrm{s} \text {. }}+1 / \mathrm{k}_{\mathrm{res}}$. The slope of the straigh line obtained by applying the least squares method to these points gives the $\mathrm{K}_{\mathrm{m}}: \mathrm{k}_{\text {res }}$ ratio, while the intercept with the $\mathrm{y}$ axis gives $1 / \mathrm{k}_{\mathrm{res}}$. The value of $\mathrm{K}_{\mathrm{m}}$ obtained $\left(2.1 \pm 0.5 .10^{-5}\right.$

Table 2. Percentages (means of five determinations \pm 1.96 standard deviation) of the main constituents of apples stored under refrigerated conditions for two periods.

\begin{tabular}{lcc}
\hline \hline & \multicolumn{2}{c}{ Storage (weeks) } \\
\cline { 2 - 3 } & 12 & 21 \\
\hline Glucose (\%) & $3.5 \pm 0.4$ & $3.1 \pm 0.1$ \\
Fructose (\%) & $8.3 \pm 0.3$ & $7.8 \pm 0.4$ \\
Sucrose (\%) & $2.4 \pm 0.2$ & $2.1 \pm 0.4$ \\
Glucitol (\%) & $0.7 \pm 0.2$ & $0.5 \pm 0.1$ \\
Malic acid (\%) & $0.5 \pm 0.1$ & $0.7 \pm 0.2$ \\
\hline
\end{tabular}

${ }^{2}$ Harvest: 39 th week of year.

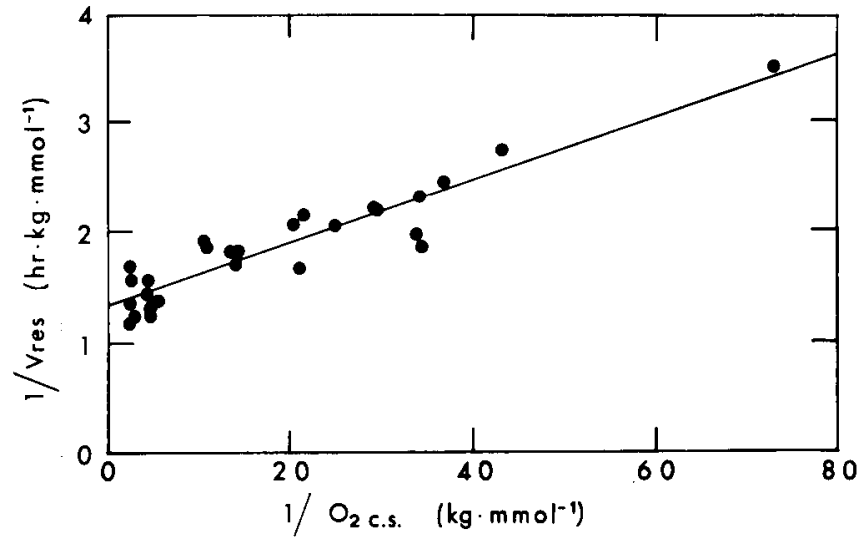

Fig. 3. Linearized form of the Michaelis-Menten equation $\left(r^{2}=\right.$ $0.86)$.

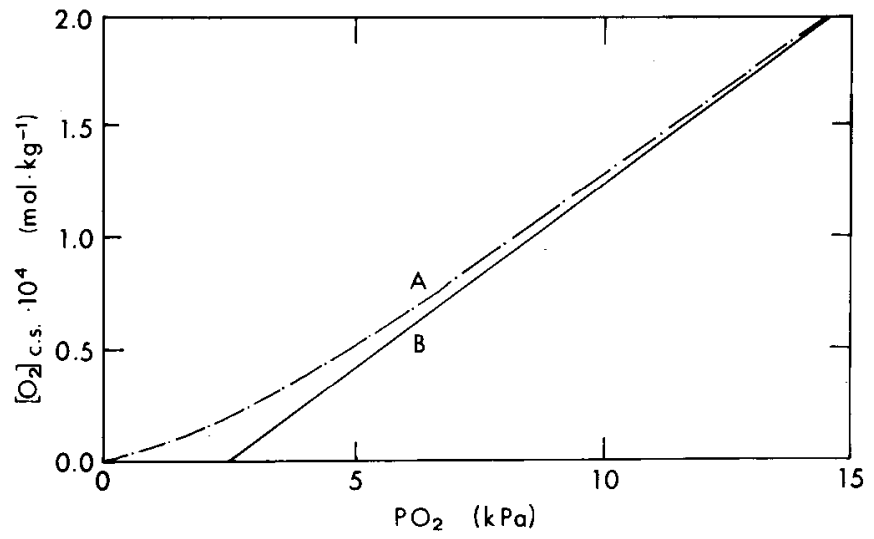

Fig. 4. $[\mathrm{O} 2]_{\text {cs. }}$ curve as a function of the $\mathrm{PO}_{2}$, employed (Eq. [2]), assuming the respiration rate $\left(\mathrm{V}_{\mathrm{res}}\right)$ : (A) constant and equal to the maximum respiration rate $\left(\mathrm{k}_{\mathrm{res}}\right) ;(\mathbf{B})$ variable with $\mathrm{PO}_{2}$ according to Eq. [7].

$\left.\mathrm{mol} \cdot \mathrm{kg}^{-1}\right)$ is of the same order of magnitude as that reported by Burton (1974) for cytochrome-c oxidase $\left(0.35 \cdot 10^{-5} \mathrm{~mol}\right.$. $\mathrm{kg}^{-1}$ ) and underlines the existence of a great affinity between oxygen and the cellular solution, justifying the low $\mathrm{PO}_{2}$ used in controlled atmosphere storage.

To detect the range of $\mathrm{PO}_{2}$ where $\mathrm{O}_{2}$ becomes the rate-determining factor, the asymptotic value of the respiration rate $\left(\mathrm{k}_{\mathrm{res}}=\right.$ maximum rate $\left.=0.75 \pm 0.06 \cdot 10^{-3} \mathrm{~mol} \cdot \mathrm{kg}^{-1} \cdot \mathrm{h}^{-1}\right)$ was introduced into Eq. [6]. In this hypothesis, Eq. [6] represents in the plane $\mathrm{PO}_{2}=\left[\mathrm{O}_{2}\right]_{\text {c.s. }}$ a straight line whose intercept with the $\mathrm{x}$ axis $(2.6 \mathrm{kPa})$ suggests the range of $\mathrm{PO}_{2}$ where $\left[\mathrm{O}_{2}\right]_{\mathrm{c.s}}$ becomes determining for the respiration rate (Fig. 4, line B). This range, evaluated at room temperature, is reasonably close to those usually used on a commercial scale in controlled atmosphere storage. When particularly low $\mathrm{PO}_{2}$ values are employed $\left(\mathrm{PO}_{2}<3.5 \mathrm{kPa}\right)$, the respiration rate greatly differs from the maximum $\left(\mathrm{k}_{\mathrm{res}}\right)$ and the more realistic shape of curve A on Fig. 4 can be calculated by combining Eqs. [6] and [7]. The basic equations and the variables, as well as the values of the constants involved in the hypothesized kinetic model, are summarized in Table 3. When the mass-transfer rate is equal to the respiration rate (steady state condition), the following expression can be obtained: $\mathrm{k}_{-\mathrm{i}} \cdot \mathrm{A} \cdot\left(\mathrm{H} \cdot \mathrm{PO} \mathrm{2}^{-}\left(\left[\mathrm{O}_{2}\right]_{\text {c.s. }}+1 /\right.\right.$ $\left.\left.\mathrm{K}_{2} \cdot\left[\mathrm{O}_{2}\right]_{\text {c.s }}\right)\right)=\mathrm{k}_{\text {res }} \cdot\left[\mathrm{O}_{2}\right]_{\text {c.s. }} /\left(\mathrm{K}_{\mathrm{p}}+\left[\mathrm{O}_{2}\right]_{\text {c.s. }}\right)$. Thus, knowing the value of the constants involved in this expression, it is possible to calculate the amount of oxygen dissolved in the cellular so- 
Table 3. Equations, variables, and constants involved in the hypothesized kinetic model.

\begin{tabular}{|c|c|}
\hline \multicolumn{2}{|l|}{ Basic equations ${ }^{z}$} \\
\hline $\begin{array}{l}\text { 1) } \mathrm{V}_{\mathrm{mt}}=\mathrm{V}_{\mathrm{res}} \\
\text { 2) } \mathrm{V}_{\mathrm{mt}}=\mathrm{k}_{-\mathrm{i}} \cdot \mathrm{A} \cdot\left(\mathrm{H} \cdot \mathrm{PO}_{2}-\left[\mathrm{O}_{2}\right]\right) \\
\text { 3) }\left[\mathrm{O}_{2}\right]=\left[\mathrm{O}_{2}\right]_{\mathrm{css}}+\left[\mathrm{O}_{2}\right]_{\mathrm{i} . \mathrm{s.}} \\
\text { 4) } \mathrm{K}_{2}=\left[\mathrm{O}_{2}\right]_{\mathrm{css}} \cdot\left[\mathrm{O}_{2}\right]_{\mathrm{i} . \mathrm{s}} \\
\text { 5) } \mathrm{V}_{\mathrm{res}}=\mathrm{k}_{\mathrm{res}} \cdot\left[\mathrm{O}_{2}\right]_{\mathrm{css}} /\left(\mathrm{K}_{\mathrm{m}}+\left[\mathrm{O}_{2}\right]_{\text {c.s. }}\right)\end{array}$ & [at steady state] \\
\hline Variables & Constants \\
\hline $\begin{array}{l}\text { 1) } \mathrm{V}_{\mathrm{mt}} \\
\text { 2) } \mathrm{V}_{\text {res }} \\
\text { 3) } \mathrm{PO}_{2} \\
\text { 4) }\left[\mathrm{O}_{2}\right] \\
\text { 5) }\left[\mathrm{O}_{2}\right]_{\text {c.s. }} \\
\text { 6) }\left[\mathrm{O}_{2}\right]_{\text {i.s. }}\end{array}$ & $\begin{aligned} \mathrm{k}_{-1} & =18.7 \pm 1.9\left[\mathrm{~kg} \cdot \mathrm{h}^{-1} \cdot \mathrm{m}^{-2}\right] \\
\mathrm{A} & =0.110 \pm 0.003\left[\mathrm{~m}^{2} \cdot \mathrm{kg}^{-1}\right] \\
\mathrm{H} & =0.14 \pm 0.02\left[\mathrm{mmol} \cdot \mathrm{kg}^{-1} \cdot \mathrm{kPa}^{-1}\right] \\
\mathrm{K}_{2} & =0.132^{\mathrm{y}} \\
\mathrm{k}_{\text {res }} & =0.75 \pm 0.06\left[\mathrm{mmol} \cdot \mathrm{kg}^{-1} \cdot \mathrm{h}^{-1}\right] \\
\mathrm{K}_{\mathrm{m}} & =0.021 \pm 0.005\left[\mathrm{mmol} \cdot \mathrm{kg}^{-1}\right]\end{aligned}$ \\
\hline
\end{tabular}

${ }^{2} \bar{F}$ or the meaning of the symbols, see Abbreviations footnote.

'The value of this constant has been calculated on the basis of the data and assumptions reported in literature (Baumann and Henze, 1983; Burton, 1974).

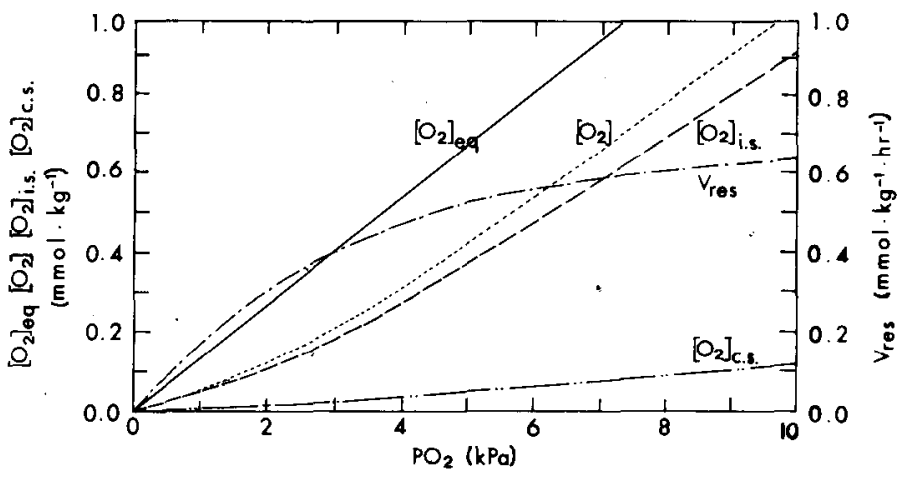

Fig.5. Calculated course of the factors involved inthe hypothesized respiratory model as a function of $\mathrm{PO}_{2}$ (see equations of Table 3 ).

lution as a function of the adopted $\mathrm{PO}_{2}$, by solving the equation: $\mathrm{a} \cdot\left[\mathrm{O}_{2}\right]_{\text {c.s. }}^{2}+\left(\mathrm{b}-\mathrm{c} \cdot \mathrm{PO}_{2}\right) \cdot\left[\mathrm{O}_{2}\right]_{\text {c.s. }}-\mathrm{d} \cdot \mathrm{PO}_{2}=0$, where: $\mathrm{a}=$ $\mathrm{k}_{-} \cdot \mathrm{A} \cdot\left(\mathrm{K}_{2}+1\right) / \mathrm{K}_{2} ; \mathrm{b}=\mathrm{k}_{-\mathrm{i}} \cdot \mathrm{A} \cdot \mathrm{K}_{\mathrm{m}} \cdot\left(\mathrm{K}_{2}+1\right) / \mathrm{K}_{2}+\mathrm{k}_{\mathrm{res}} ; \mathrm{c}=$ $\mathrm{k}_{-\mathrm{i}} \cdot \mathrm{A} \cdot \mathrm{H} ; \mathrm{d}=\mathrm{k}_{-\mathrm{i}} \cdot \mathrm{A} \cdot \mathrm{H} \cdot \mathrm{K}_{\mathrm{m}} \cdot \mathrm{As}\left[\mathrm{O}_{2}\right]_{\text {c.s. }}$ cannot be a negative number, only the following solution can be accepted: $\left[\mathrm{O}_{2}\right]_{\text {c.s. }}$. $=\left(-\left(b-c \cdot P_{2}\right)+\left(\left(b-c \cdot P_{2}\right)^{2}+4 \cdot a \cdot d \cdot P_{2}\right)^{0.5}\right) /(2 \cdot a)$. The amount of $\mathrm{O}_{2}$ dissolved in the cellular solution being known, it is possible to calculate the other variables involved in the adopted kinetic model using the equations given in Table 3 .

Figure 5 depicts the theoretical development of $\mathrm{V}_{\text {res }}$ together with those of the different bases of $\mathrm{O}_{2}$ involved in the hypothesized respiratory model.

Because of its restricted applicability, this model represents only a preliminary and basic study in a wider research program concerning fruit storage in cold and controlled atmospheres, its aim being to correlate the main quality changes of a fruit with time and storage conditions.

\section{Literature Cited}

Andrich, G., R. Fiorentini, and A. Tuci. 1987. A mathematical model describing oxygen exchange between apples and storage environment, p. 90-92. In: A. Spadoni and C. Peri (eds.). Conservation and processing of foods. C. N. R., Rome.

Andrich, G., R. Fiorentini, C. Galoppini, and A. Tuci. 1988. Skin permeability to carbon dioxide in apples stored in controlled atmo- sphere. Proc. Postharvest 88, 28 Aug.-2 Sept. 1988, Leuven, Belgium. p. 193-198.

Andrich, G., R. Fiorentini, A. Tuci, and C. Galoppini. 1989a. Skin permeability to oxygen in apples stored in controlled atmosphere. J. Amer. Soc. Hort. Sci. 114(5):770-775.

Andrich, G., R. Fiorentini, A. Tuci, and A. Zinnai. 1989b. Skin permeability to oxygen in apples stored at low temperatures. Ital. J. Food Sci. 1(2):35-43.

Andrich, G., R. Fiorentini, C. Galoppini, A. Tuci, G. Sommovigo, and A. Zinnai. 1990. Skin permeability to carbon dioxide in apples at different ripening times. Lebensm.-Wiss. und Technol. 23:162164.

Baumann, H. and J. Henze. 1983. Intercellular space volume of fruit. Acts Hort. 138:107-111.

Biale, J.B. and R.E. Young. 1981. Respiration and ripening in fruits, part 1. Retrospect and prospect, p. 1-39. In: G. Friend and M.J.C. Rhodes (eds.). Recent advances in the biochemistry of fruits and vegetables. Academic, London.

Burton, W.G. 1974. Some biophysical principles underlying the controlled atmosphere storage of plant material. Ann. Applied Biol. 78:149-168.

Burton, W.G. 1978. Biochemical and physiological effects of modified atmospheres and their role in quality maintenance, p. 97-1 10. In: H.O. Hultin and M. Miller (eds.). Postharvest biology and technology. Food and Nutrition Press, Westport, Corm.

Danckwerts, P.V. 1970. Diffusion and volubility in liquids. Gas-liquid reactions. McGraw-Hill, New York. p. 97-98.

Fiorentini, R., G. Andrich, and C. Galoppini. 1986. A mathematical model describing gas exchange between fruit and storage environment. Proc. XXIInd Intl. Hort. Congress, 10-18 Aug. 1986, Davis, Calif. p. 780.

Isenberg, F.M.R. 1979. Controlled atmosphere storage of vegetables. Hort. Rev. 1:337-394.

Knee, M. 1971. Ripening of apples during storage. J. Sci. Food Agr. 22:365-377.

Sinclair, C.G. 1987. Microbial process kinetics, p. 75-150. In: J. Bu'lock and B. Kristiansen (eds.). Basic biotechnology. Academic, London.

Smock, R.M. 1979. Controlled atmosphere storage of fruits. Hort. Rev. 1:301-336.

Tucker, M.L. and G.G. Laties. 1985. The dual role of oxygen in avocado fruit respiration: kinetic analysis and computer modelling of diffusion-affected respiratory oxygen isotherms. Plant Cell \& Env. $8: 117-127$. 